\title{
Pengaruh Program Kampung UKM Digital terhadap Omzet Penjualan (Studi Kasus UKM Batik Kayu Krebet, Pajangan, Bantul)
}

\author{
Ahmad Yunadi dan Wiwik Ardiyanti \\ Fakultas Ekonomi Bisnis Universitas Alma Ata \\ Jl. Brawijaya No. 99 Yogyakarta \\ email:yunadi444@gmail.com
}

\begin{abstract}
This study aims at determining the difference in sales turnover before and after using the digital SME village program at the Batik Kayu Krebet Studio, Sendangsari Pajangan Bantul. This studio had received digital SME village program from the Regional Government of Bantul. Batik Kayu Krebet Studio is one of the receiver of 5 digital village SME programs. The sales turnover used in this research is turnover obtained through conventional marketing and online through; Facebook, Instagram, Website, Blanja.com, and Qlapa.

The data in this study are quantitative and qualitative data using mixed data. Data were obtained from 5 Batik Kayu Krebet Studios which received digital SME village program grants. The method of data analysis used in this study was paired sample t-test and the Wilxocon signed rank test.

The results of paired sample $t$-test showed that there was a significant difference between sales turnover before and after using digital SME village program facilities with paired sample t-test while the result of sig-2 tailed 0.36. Meanwhile, the test results of wilxocon signed rank test had a $Z$ value of -2.023 , with a 2 - tailed significance of 0.043 . This means that the significance value is $0.043<0.05$, so Ho is rejected or there is a difference in sales turnover before and after using digital SME village program facilities.
\end{abstract}

Keywords: Turnover, Sales, SME, Digital

\begin{abstract}
Abstrak
Penelitian ini bertujuan untuk mengetahui perbedaan omzet penjualan sebelum dan sesudah menggunakan program kampung UKM digital pada Sanggar Batik Kayu Krebet Sendangsari Pajangan Bantul yang mendapatkan program kampung UKM digital dari Pemerintah Daerah Bantul. Sanggar Batik Kayu di dusun Krebet yang mendapatkan program kampung UKM digital sebanyak 5 sanggar. Omzet penjualan yang dipakai adalah omzet yang didapatkan melalui pemasaran konvensional dan online melalui; Facebook, Instagram, Website, Blanja.com, dan Qlapa.

Data dalam penelitian ini merupakan data kuantitatif dan kualitatif dengan menggunakan data campuran. Data diperoleh dari 5 Sanggar Batik Kayu Krebet yang mendapatkan hibah program kampung UKM digital. Metode analisis data yang digunakan peneliti dalam penelitian ini adalah menggunakan uji paired sample t test dan uji wilxocon signed rank test.

Hasil penelitian yang di dapat dengan menggunakan uji paired sample t test menunjukkan bahwa terdapat perbedaan yang signifikan antara omzet penjualan sebelum dan sesudah menggunakan fasilitas program kampung UKM digital dengan uji paired sample t test, adapun hasil uji taraf sig-2 tailed 0,36. Sedangkan hasil uji dengan wilxocon signed rank test mempunyai taraf nilai Z sebesar -2,023, dengan signifikansi 2- tailed sebesar 0,043. Artinya nilai signifikansi 0,043< 0,05, maka Ho ditolak atau ada perbedaan omzet penjualan sebelum dan sesudah menggunakan fasilitas program kampung UKM digital.
\end{abstract}

Kata kunci: Omzet, Penjualan, UKM, Digital. 


\section{PENDAHULUAN}

Dalam perkembangan dan kemajuan zaman sekarang ini, perekonomian dunia menuntut kita untuk mencari peluang kerja dan berkarya dengan kreatif agar mendapat pekerjaan atau industri yang potensial untuk memenuhi pendapatan yang maksimal sehingga memenuhi kebutuhan hidup. Dengan adanya persaingan global, banyak bermunculan Usaha Kecil Menegah (UKM) yang ingin mengembangkan usahanya untuk memperoleh kemajuan dalam dunia bisnis dan berkarya, yang mana setiap UKM bertujuan untuk meningkatkan perekonomian dan mengurangi angka penganguran (Tika Nur Arifah, 2015).

Perintah bekerja atau berkarya tersebut telah disebutkan dalam Al-Qur'an surat AlQashash ayat 77:

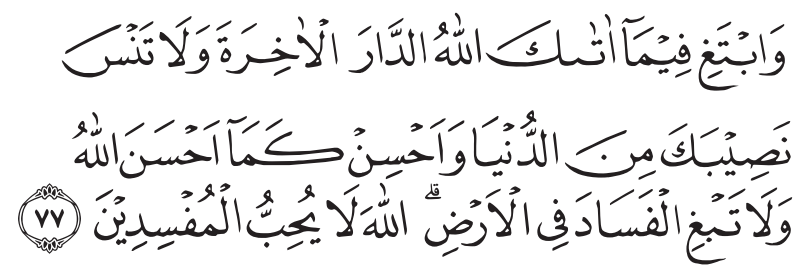

Artinya:

"Dan carilah pada apa yang telah dianugerahkan Allah kepadamu (kebahagiaan) negeri akhirat, dan janganlah kamu melupakan bahagianmu dari (kenikmatan) duniawi dan berbuat baiklah (kepada orang lain) sebagaimana Allah telah berbuat baik, kepadamu, dan janganlah kamu berbuat kerusakan di (muka) bumi. Sesungguhnya Allah tidak menyukai orang-orang yang berbuat kerusakan".

UKM merupakan salah satu sektor industri yang sedikit bahkan tidak sama sekali terkena dampak krisis global yang melanda dunia. Dengan bukti ini, jelas bahwa UKM dapat diperhitungkan dalam meningkatkan kompetitif pasar dan stabilisasi sistem ekonomi yang ada. (Departemen Koperasi, 2008).

Globalisasi juga telah menjadi aspek yang memberikan pengaruh besar terhadap perubahan sosial yang terjadi di berbagai negara. Salah satunya di negara berkembang seperti Indonesia. Pengaruh tersebut mengubah arah gerak manusia di berbagai sektor kehidupan mulai dari bidang ekonomi, sosial, budaya, keamanan, dan teknologi akhirakhir ini. Teknologi informasi dan komunikasi, khususnya internet, selama ini identik dengan kalangan menengah atas dan didominasi orangorang kaya atau masyarakat kota. Namun, kini teknologi informasi dan komunikasi mulai bergeser ke kampung-kampung. Internet pun kini mulai masuk ke kalangan menengah ke bawah dan masyarakat desa.

Permasalahan yang mendasar di UKM yang terjadi sejak dulu adalah sulitnya dalam menangani permintaan yang besar dari konsumen dan kekurangan modal. Hal ini sangat ironis karena pemerintah memiliki program yang menawarkan bantuan terhadap usaha semacam KUR (Kredit Usaha Rakyat), namun program cenderung belum mencapai target karena persyaratan untuk mendapatkan modal dari pihak bank yang akan memberikan pinjaman mewajibkan pihak kelompok usaha untuk memberikan jaminan. Pemasaran juga merupakan salah satu problem bagi pelaku UKM, hal ini dikarenakan untuk memasarkan produk ke pasar yang lebih luas para pelaku UKM membutuhkan biaya yang tidak sedikit. Sehingga besarnya biaya pemasaran membuat pelaku UKM menitipkan barang ke tengkulak, sehingga harga barang yang dijual tidak stabil, dan tidak jarang para tengkulak memberikan harga jual yang sangat tinggi kepada konsumen.

Melihat beberapa permasalahan di UKM, Pemerintah Kabupaten Bantul DIY bekerjasama dengan PT Telkom memberikan solusi bagi para UKM dalam melakukan pemasaran dengan memberikan bantuan Program kampung UKM Digital. Peluncuran Kampung UKM digital ini merupakan program pemberdayaan masyarakat UMKM melalui upaya mendorong pemanfaatan teknologi informasi dan komunikasi (Sulistyanto, 2016). Program Kampung UKM digital di Bantul khususnya di Kecamatan Pajangan Desa Sendangsari Dusun Krebet difasilitasi jaringan kabel optik dari PT Telkom sejak Agustus 2016. Hal ini bertujuan untuk meningkatkan akses pasar dan omzet penjualan produk UKM terutama di sentra kerajinan batik kayu Dusun Krebet yang diharapkan akan berdampak pada peningkatan ekonomi kabupaten Bantul (Agus Untoro, 2016). 
Program kampung UKM digital yang diluncurkan oleh PT Telkom pada enam titik hotspot itu memberikan antusias masyarakat yang tinggi untuk memasarkan produk batik kayu secara online. Dengan demikian perlu adanya penelitian yang membuktikan apakah ada Pengaruh Program Kampung UKM Digital di UKM Batik Kayu Krebet, Pajangan, Bantul yang mendapatkan program tersebut terhadap omzet penjualan. Program kampung UKM digital merupakan program baru yang di luncurkan oleh PEMDA Bantul, sehingga penelitian sebelumnya terkait hal ini belum ada yang melakukan.

\section{METODE PENELITIAN}

Jenis penelitian ini menggunakan metode campuran (Mixed Method), yaitu metode yang memadukan pendekatan kualitatif dan kuantitatif dalam hal metodologi (seperti dalam tahap pengumpulan data), dan kajian model campuran memadukan dua pendekatan dalam semua tahap proses penelitian.

Mixed Method juga disebut sebagai sebuah metodologi yang memberikan asumsi filosofis dalam menunjukkan arah atau memberi petunjuk cara pengumpulan data dan menganalisis data serta perpaduan pendekatan kuantitatif kualitatif melalui beberapa fase proses penelitian (Sugiono, 2013)

Strategi metode campuran yang digunakan dalam penelitian ini adalah urutan analisis kuantitatif dan kualitatif, tujuan strategi ini adalah untuk mengidentifikasi komponen konsep melalui analisis data kuantitatif dan kemudian mengumpulkan data kualitatif guna memperluas informasi yang tersedia. Intinya adalah untuk menyatukan data kuantitatif dan kualitatif agar memperoleh analisis yang lebih lengkap (Sugiono, 2013)

Metode kuantitatif digunakan untuk mencari data yang terukur mengenai omzet penjualan sebelum dan sesudah menggunakan program kampung UKM di Krebet Kecamatan Pajangan Kabupaten Bantul Yogyakarta.

Sedangkan metode kualitatif digunakan untuk mendapatkan informasi mengenai UKM digital, dan omzet penjualan batik kayu selama 4 bulan sebelum dan sesudah mengikuti program kampung UKM digital serta informasi mengenai sejarah UKM yang ada di Krebet Kecamatan Pajangan Kabupaten Bantul Yogyakarta.

Penelitian ini dirancang dengan menggunakan pendekatan eksplanatoris sekuensial. Dalam strategi ini tahap pertama adalah menggunakan dan menganalisis yang dibangun berdasarkan hasil awal kualitatif. Bobot atau prioritas ini diberikan pada data kuantitatif (John W. Creswell 2010). Jadi tahap pertama yaitu melakukan wawancara kemudian menganalisis data kuantitatif. Yaitu mengetahui pemasaran online yang sudah diterapkan dalam UKM digital selanjutnya akan dilakukan penyebaran instrumen penelitian dan menganalisis data kuantitatif untuk mengetahui omzet penjualan setiap sanggar sebelum dan sesudah menggunakan kampung UKM digital.

\section{Bahan dan Alat Penelitian}

Pada dasarnya instrumen penelitian adalah pengumpulan data dan alat bantu untuk mendapatkan alat bantu empiris lapangan secara tepat dan berhasil guna (efektifdan efisien) (Supardi, 2005). Dan untuk menguji skala pengukuran dalam penelitian ini digunakan uji normalitas, uji paired smple $t$-tes, dan uji wilxocon signed ranks test.

\section{Pengolahan dan Analisis Data}

Penelitian ini membandingkan Omzet Penjualan sebelum dan sesudah menggunakan kampung UKM digital selama 4 bulan sebelum adanya kampung UKM digital dan 4 bulan setelah adanya UKM digital. Periode penelitian dapat digambarkan sebagai berikut:

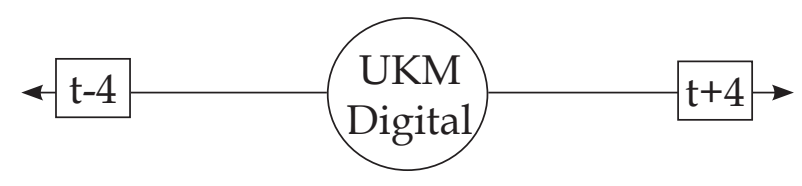

\section{Gambar 1. Periode Penelitian}

Pengujian statistik dilakukan dengan menggunakan program SPSS versi 20. Analisis data dilakukan dengan 4 tahap yaitu: pengujian normalitas, pengujian uji beda t-test (paired sample t-test), dan pengujian wilcoxon signed rank test. 
Uji beda ini dilakukan untuk melihat perbedaan rata-rata variabel yang diuji. Pengujian ini digunakan untuk menguji variabel omzet penjulan yaitu dengan uji paired sample t-test dan uji wilcoxon signed rank test. Kedua pengujian ini dilakuakan untuk hasil yang lebih kuat. Untuk lebih jelasnya maka pengujian-pengujian tersebut akan diuraikan dibawah ini:

\section{Uji Paired Sample T-Test}

Uji Paired Sample T-Test merupakan salah satu pengukuran statistik parametik. Statistik parametik merupakan bagian dari statistik inferensial yang parameter dari populasinya mengikuti suatau distribusi tertentu, seperti distribusi normal dan memiliki varians yang homogen. Kelebihan dari pengguna pengukuran statistik parametik adalah kesimpulan yang diperoleh lebih kuat jika dibandingkan dengan kesimpulan yang diperoleh dari analisis statistik non parametrik.

Paired Sample T-Test menguji dua sampel yang berpasangan, untuk menganalisis apakah kedua sampel yang berhubungan tersebut memiliki rata-rata yang secara nyata berbeda ataukah tidak. Pengujian dua sampel berpasanagan bertujuan untuk menguji beda rata-rata berpasangan antara dua sampel yang berhubungan. Pengujian ini dilakukan terhadap dua sampel yang berpasangan (paired). Sampel yang berpasangan diartikan sebagai sebuah sampel dengan subyek yang sama, namun mengalami dua perlakuan atau pengakuan yang berbeda. Uji Paired Sample T-Test ini dugunakan untuk menguji rata- rata setiap variabel antara sebelum dan sesudah dilakuknya program UKM digital (Sunjoko, 2008).

\section{Uji Wilcoxon Signed Rank Test}

Uji wilcoxon signed rank test digunakan untuk menganalisis hasil-hasil pengamatan yang berpasangan dari dua data apakah berbeda atau tidak. Wilcoxon signed Rank Test ini digunakan hanya untuk data bertipe interval atau ratio.

Uji wilcoxon signedrank test ini digunakan untuk memperkuat hasil uji beda paired simple t-test serta melihat uji beda pada variabel omzet penjualan yang menggunakan UKM digital (Sugiyono, 2005).
Adapun langkah-langkah perumusan hipotesis dan kriteria penerimaan dari uji beda sebagai berikut:

1) Jika Sig di atas 0,05 maka Ho diterima (tidak ada perbedaan)

2) Jika Sig di bawah 0,05 maka Ho ditolak (ada perbedaan).

\section{HASIL DAN PEMBAHASAN}

UKMbatikkayudidesaKrebetmerupakan hasil karya masyarakat dusun Krebet sebagai bentuk proses kehidupan sosial di dusun Krebet. UKM batik kayu Krebet mempunyai sejarah yang panjang dan mengesankan. Sejarah tentang munculnya UKM batik kayu krebet digali secara periodik menurut para pelaku sejarah, pengalaman-pengalamannya berkerajinan dan perjuangannya menciptakan kerajinan.

UKM batik kayu di dusun Krebet mulai dikenal masyarakat luas melalui kerajinan kayu yang dibuat beberapa perajin senior seperti Gunjiar (63), Warno (Alm), Kemiskidi (51), Anton Wahono (52), dan Windiarti, turut menguntai sejarah munculnya kerajinan batik kayu di dusun Krebet.

Kisah Gunjiar, konon menurut cerita sekitar tahun 1972-an, Gunjiar yang saat itu mempunyai pekerjaan membuat pisau terkena musibah digigit ular berladang. Selama 35 hari tidak dapat berjalan dan selama sakit Gunjiar tidak dapat bekerja. Sampai suatu ketika ada seseorang datang dan memesan sebuah topeng. Gunjiar merasa tertantang dan melalui nyantrik di mbah Warno topeng pesanan dapat beliau selesaikan dengan baik.

Sekitar tahun 1980-1985 kerajinan belum diminati oleh masyarakat Krebet sebagai mata pencaharian. Sanggar-sanggar pada saat itu masih sedikit. Mata pencaharian mereka masih banyak sebagai petani dan buruh membatik. Hal ini menjadi wajar karena masyarakat masih tergolong miskin dan berpendidikan yang rendah. Seiring berjalannya waktu munculah satu per satu dari warga Krebet untuk mencoba bekerja sekaligus belajar membatik dan di Sanggar Punokawan dan Sanggar Peni. Dikala itu kerajinan batik kayu di Krebet masih wayang klithik dan topeng dengan finishing cat. 
Perkembang batik kayu di Krebet diawali dengan magang/nyantrik. Proses nyantrik diawali dari penggarapan pesanan di Sanggar Windarti. Untuk memenuhi pesanan yang banyak maka Windarti merekrut beberapa karyawan untuk membantunya. Karyawannya sendiri adalah tetangga yang terdiri adalah ibu-ibu dan remaja putri yang ada di dusun Krebet. Selain itu, Windarti juga merekrut beberapa pemuda untuk bekerja membuat putihan, pengamplasan, tenaga pewarnaan, maupun penjemuran.

Teknik membatik yang menyebar di Krebet ini di populerkan oleh Windarti mulai dari membangkitkan para perajin kayu untuk mem-finishing kerajinannya dengan batik. Banyaknya peminat terhadap kerajinan batik kayu ini membuat kerajinan berkembang pesat. Satu per satu sanggar batik kayu muncul di era sekitar tahun 1995-an. Sanggar-sanggar itu muncul dengan sejarah yang berbeda-beda. Akan tetapi sanggar itu mempunyai tujuan yang hampir sama yaitu meningkatkan perekonomian serta mensejahterakan masyarakat khususnya dusun Krebet. Berawal dari 5 Sanggar, berkembang menjadi 10 Sanggar kemudian menjadi 42 Sanggar hingga sekarang berkembang pesat menjadi 57 Sanggar Batik Kayu yang ada di Krebet (Kemiskidi, 2016).

Penelitian ini menggunakan data 4 bulan sebelum menggunakan program kampung UKM digital dan 4 bulan setelah mengunakan program Kampung UKM digital. Penelitian ini membandingkan omzet penjualan sebelum menggunakan program kampung UKM digital dengan omzet penjualan setelah menggunakan program kampung UKM digital. Sampel diperoleh sebanyak 5 sanggar selama Agustus 2016 hingga Maret 2017 yang telah menggunakan program kampung UKM digital.

Tujuan dari penelitian sebelum dan sesudah ini adalah untuk melihat perkembangan omzet penjualan pada masing-masing sanggar sebelum dan sesudah mendapatkan fasilitas kabel optik/UKM digital. Variabel-variabel yang digunakan dalam penelitian ini adalah pelanggan, toko, facebook, instagram, qlapa, blanja.com, dan omzet penjualan. Ketujuh variable tersebut diperoleh dari sanggar batik kayu Krebet.
Uji statistik deskriptif dilakukan dengan tujuan untuk memberikan gambaran atau deskripsi dari variabel variabel yang diteliti. Dalam penelitian ini ditunjukkan hasil angka minimum, maksimum, mean, dan standar deviasi dari masing-masing variabel.

Dari 5 sanggar batik kayu variabel omzet penjualan sebelum menggunakan program kampung UKM digital pada nilai minimum adalah sebesar Rp. 60.855.000, dan nilai maksimum adalah Rp. 293.405.000, mean sebesar Rp.173.117.000, dengan standar deviasi sebesar Rp. 85.905.152,829. Sedangkan variabel omzet penjualan setelah menggunakan program kampung UKM digital nilai minimum adalah sebesar Rp. 70.755.000, nilai maksimum sebesar Rp. 350.920.000, mean sebesar Rp. 220.577.618, dengan standar deviasi sebesar Rp.104.848.022.936. Rata-rata omzet penjualan sebelum dan sesudah menggunakan program kampung UKM digital memiliki nilai yang lebih besar daripada standar deviasinya. Itu Artinya omzet penjualan telah terdistribusi dengan normal.

Sebelum dilakukan pengujian data, perlu dilakukan analisis data yang diperoleh dari data mentah (raw data) yang diperoleh dari pengumpulan data. Analisis dilakukan dengan cara membandingkan nilai omzet penjualan sebelum dan sesudah dari sanggar sampel selama 4 bulan sebelum dan 4 bulan sesudah menggunakan kampung UKM Digital.

Adapun Sanggar Batik Kayu yang menggunakan program kampung UKM digital meliputi Sanggar Prima, Yuan Art, Dewi Sri, Ragil Handicraft, dan Sanggar Peni. Data omzet penjulan yang diperoleh sebelum dan sesudah menggunakan kampung UKM digital adalah sebagaimana ditunjukkan pada Tabel 1.

Tabel 1. menunjukkan bahwa data 5 sanggar selama 4 bulan sebelum menggunakan kampung UKM digital omzet penjualan pada setiap sanggar hampir mengalami peningkatan setiap bulannya, kecuali pada Sanggar Yuan Art, Dewi Sri, dan Ragil Handicraft yang mengalami penurunan pada bulan September hingga Oktober. Dan secara pengamatan dapat dikatakan bahwa omzet penjulan lebih dominan mengalami peningkatan pada 5 sanggar tersebut. 
Tabel 2 menunjukkan data 5 sanggar selama 4 bulan setelah menggunakan kampung UKM digital. Dari tabel diatas dapat dilihat bahwa omzet penjualan mengalami peningkatan kecuali pada sanggar Prima mengalami penurunan pada bulan Agustus sampai Oktober. Sedangkan pada Sanggar Sewi Sri mengalami penurunan pada bulan Agustus sampai September, dan Sanggar Ragil mengalami penurunan omzet pada bulan September sampai Oktober.

Hasil uji normalitas menunjukan bahwa tingkat signifikansinya adalah 0,978 yang berarti lebih besar dari 0,05. Hasil ini berarti bahwa Ho ditolak atau dapat diartikan data telah terdistribusi dengan normal.

\section{Uji Paired Sample T-Test}

Untuk menguji ada perbedaan atau tidak dari omzet penjualan sebelum dan sesudah menggunakan program kampung UKM digital maka dilakukan uji paired sample t-test dengan SPSS versi 20,0. Penelitian ini menggunakan taraf signifikansi $5 \%(0,05)$. Hasil uji paired sample t-test dengan melalui analisis SPSS, dapat diketahui perbedaan omzet penjualan sebelum dan sesudah menggunakan program kampung UKM digital yang ditunjukkan dengan hasil ujibeda omzet penjualan sebelum dan sesudah menggunakan program kampung UKM digital. Dari hasil analisis tersebut diperoleh $t$ hitung sebesar $-3,098$ dan nilai signifikansinya sebesar 0,036 yang berarti lebih kecil dari tingkat signifikansi 0,05 (Ho ditolak). Dengan demikian dapat disimpulkan bahwa terdapat perbedaan pada omzet penjualan sebelum dan sesudah menggunakan program kampung UKM digital.

\section{Uji Wilcoxon Signed Rank Test}

Untuk memperkuat hasil ujibeda paired simple t-test serta melihat ujibeda pada omzet penjualan sebelum dan sesudah menggunakan program kampung UKM digital maka perlu adanya uji wilcoxon signed rank test. Uji wilxocon signed ranks test berfungsi untuk menganalisis hasil-hasil pengamatan yang berpasangan dari dua data apakah berbeda atau tidak. Wilcoxon signed Rank Test ini hanya digunakan untuk data bertipe interval atau ratio.

Dari penjelasan output tabel 1.5 dapat disimpulkan bahwa; Negative Ranks atau selisih antara omzet penjualan sebelum dan sesudah menggunakan program kampung UKM digital sebesar 0,00 observasi. Artinya tidak ada selisih rangking dari sebelum dan sesudah menggunakan program kampung UKM digital. Positive Ranks atau selisih antara omzet

Tabel 1. Omzet Penjualan Sanggar Batik Kayu Krebet Sebelum Menggunakan Program Kampung UKM Digital

\begin{tabular}{lrrrrr}
\hline \multicolumn{1}{c}{ Nama Sanggar } & Agustus 2016 & September 2016 & Oktober 2016 & Nopember 2016 & Jumlah \\
\hline Prima Batik & 13.700 .000 & 15.110 .000 & 15.800 .000 & 16.245 .000 & 60.855 .000 \\
Yuan Art & 33.510 .000 & 36.915 .000 & 35.370 .000 & 38.135 .000 & 143.930 .000 \\
Dewi Sri & 49.400 .000 & 54.475 .000 & 51.005 .000 & 55.000 .000 & 209.880 .000 \\
Ragil Handicraft & 38.450 .000 & 40.060 .000 & 37.430 .000 & 41.575 .000 & 157.515 .000 \\
Peni & 69.720 .000 & 75.045 .000 & 74.320 .000 & 74.320 .000 & 293.405 .000 \\
\hline \multicolumn{1}{c}{ JUMLAH } & $\mathbf{2 0 4 . 7 8 0 . 0 0 0}$ & $\mathbf{2 2 1 . 6 0 5 . 0 0 0}$ & $\mathbf{2 1 3 . 9 2 5 . 0 0 0}$ & $\mathbf{2 2 5 . 2 7 5 . 0 0 0}$ & $\mathbf{8 6 5 . 5 8 5 . 0 0 0}$ \\
\hline
\end{tabular}

Data Sekunder: diolah oleh peneliti.

Tabel. 2 Omzet Penjualan Sanggar Batik Kayu Krebet Sesudah Menggunakan Program Kampung UKM Digital

\begin{tabular}{lrrrrr}
\hline \multicolumn{1}{c}{ Nama Sanggar } & \multicolumn{1}{c}{ Desember 2016 } & Januari 2017 & Februari 2017 & Maret 2017 & \multicolumn{1}{c}{ Jumlah } \\
\hline Prima Batik & 17.560 .000 & 17.230 .000 & 16.405 .000 & 19.500 .000 & 70.695 .000 \\
Yuan Art & 41.119 .000 & 42.448 .000 & 43.635 .000 & 45.821 .000 & 173.023 .000 \\
Dewi Sri & 62.985 .000 & 59.780 .000 & 63.205 .000 & 64.370 .000 & 250.340 .000 \\
Ragil Handicraft & 60.825 .090 & 65.590 .000 & 63.860 .000 & 67.575 .000 & 257.850 .090 \\
Peni & 83.640 .000 & 86.030 .000 & 89.175 .000 & 92.075 .000 & 350.920 .000 \\
\hline \multicolumn{1}{c}{ JUMLAH } & $\mathbf{2 6 6 . 1 2 9 . 0 9 0}$ & $\mathbf{2 7 1 . 0 7 8 . 0 0 0}$ & $\mathbf{2 7 6 . 2 8 0 . 0 0 0}$ & $\mathbf{2 8 9 . 3 4 1 . 0 0 0}$ & $\mathbf{1 . 1 0 2 . 8 2 8 . 0 9 0}$ \\
\hline
\end{tabular}

Data Sekunder: olahan peneliti. 
penjualan sebelum dan sesudah menggunakan kampung UKM digital yang positif sebanyak 5 observasi atau dengan kata lain terdapat 5 observasi pada omzet penjulan sesudah yang lebih dari observasi sebelumnya, yaitu dengan rata-rata rangkingnya sebesar 3,00 dan jumlah rangking positifnya adalah sebesar 15,0 . Ties bernilai 0 , artinya adanya perbedaan omzet penjulan sebelum dan sesudah menggunakan program kampung UKM digital.

Hasil analisis data pada tabel $1.6 \mathrm{di}$ atas dengan perbandingan omzet penjualan sebelum dan sesudah menggunakan kampung UKM digital, dapat diperoleh nilai $Z$ sebesar -2,023, dengan signifikansi 2-tailed sebesar 0,043 . Artinya nilai signifikansi 0,043<0,05.

\section{PEMBAHASAN}

Hasil pengujian hipotesis paired sample t-test dengan menggunakan SPSS ditemukan bukti bahwa nilai t hitung sebesar -3,096 dan nilai signifikansinya sebesar 0,036 yang berarti lebih kecil dari tingkat signifikansi 0,05 (Ho ditolak). Dengan demikian dapat disimpulkan bahwa terdapat perbedaan pada omzet penjualan sebelum dan sesudah menggunakan program kampung UKM digital, sehingga hipotesis diterima. Hasil penelitian ini mendukung penelitian yang dilakukan oleh Tri Udiono (2007) yang meneliti tentang Perbedaan Prestasi Belajar Mahasiswa Sebelum dan Sesudah mengikuti Program Remidial yang berhasil terdapat perbedaan sebelum dan sesudah mengikuti program remidial. Sedangkan hasil pengujian dari wilxocon signed ranks test telah dibuktikan dengan angka $Z$ sebesar -2,023, dengan signifikansi 2 -tailed sebesar 0,043 . Artinya nilai signifikansi $0,043<0,05$, maka Ho ditolak (ada perbedaan).

Dalam dunia usaha/bisnis, omzet merupakan sebuah kunci utama untuk mengembangkan usaha kita, cara meningkatkan omzet penjualan melalui penjualan merupakan gambaran akan potensi suksesnya bisnis tersebut, untuk seorang marketing sudah bukan hal yang asing lagi, hampir $80 \%$ sales/ marketing di sebuah perusahaan di target omzet per tiga bulan dan per tahun. Begitu pula sebaliknya apabila omzet penjualan kita menurun maka akan menurun pula potensi suksesnya usaha yang kita bangun.

Sesuai hasil wawancara dengan bapak Yulianto/sekretaris Koperasi Sido Katon sekaligus owner Sanggar Yuan Art dijelaskan bahwa: "Semua Sanggar yang ada di Krebet dapat dikatakan usaha menengah keatas. UKM Batik kayu ini berjumlah 57 Sanggar, akan tetapi yang menggunakan program kampung UKM digital/ yang telah mendapatkan fasilitas kabel optik dari PT Telkom hanya terdapat 5 Sanggar yakni Sanggar Yuan Art, Sanggar Prima Batik Kayu, Sanggar Peni, Ragil Handicraft, Sanggar Dewi Sri.

Awal mula mendapatkan fasilitas kabel optik dari PT Telkom, 5 sanggar yang ada di Krebet ini mengadakan pelatihan-pelatihan untuk memasarkan produknya melalui online. Adapun PT Telkom sendiri memberikan fasilitas berupa aplikasi Blanja. Com yang nantinya dapat digunakan sebagai media pemasaran bagi 5 sanggar tersebut. Menurut owner dari masing-masing sanggar aplikasi blanja.com ini sangat susah di aplikasikan sebagai media pemasaran. Alasanya pertama, karena susahnya mengupload foto produk sebagai pemasaran dikarenakan jaringan yang bermasalah, kedua, aplikasi ini bersifat umum (semua produk masuk), ketiga, kurang fahamnya dalam mengaplikasikan blanja.com.

Dari permasalahan di atas, 5 sanggar tersebut menggunakan media lainnya sebagai alternatif pemasaran online. Adapun fasilitas yang digunakan dalam memasarkan produknya berupa faceebook, instagram, website, dan qlapa.com. Untuk pemasaran offline sanggar tersebut sudah memiliki pelanggan, dan toko di rumah masingmasing sanggar.

Pemasaran online yang sudah berjalan kurang lebih 4 bulan ini, sudah lumayan meningkat, karena pada dasarnya pemasaran awal kepada konsumen baru itu kurang lebih 6 bulan untuk mendapatkan pelanggan. Meskipun demikian pemasaran melalui instagram, facebook, dan website banyak ditanggapai oleh konsumen. Apalagi apikasi qlapa.com telah mampu merangkul konsumen untuk menjadi pelanggan. Hal ini terbukti dengan omzet penjualan pada Sanggar Peni yang mengalami peningkatan dalam pemasaran online melalui aplikasi qlapa.com. Secara keseluruhan adanya kabel optik ini sangat membantu bagi pengusaha batik kayu untuk memasarkan produknya yang nantinya akan mendunia, bahkan secara perlahan omzet penjualan sudah mengalami peningkatan bagi sanggar UKM digital. 
Dari hasil wawancara diatas dapat disimpulkan bahwa adanya fasilitas kabel optik yang diberikan oleh PT.Telkom dapat meningkatkan omzet penjualan pada UKM sanggar batik kayu yang ada di Krebet. Penggantian aplikasi blanja.com yang dilakukan oleh masing-masing Sanggar tidak menjadi masalah bagi PT.Telkom, asal dapat meningkatkan volume penjualan. Akan tetapi PT.Telkom juga akan memperbaiki supaya fasilitas pemasaran blanja.com dapat digunakan semestinya oleh masyarakat Krebet melalui pelatihan.

Untuk menganalis itu, kita harus mengetahui faktor-faktor yang mempengaruhi turun dan meningkatnya omzet penjualan. Adapun stategi meningkatkan omzet penjualann adalah sebagai berikut: Kondisi dan Kemampuan Penjual, Kondisi Pasar, Modal, Kondisi Organisasi Perusahaan, Faktor-faktor lain, seperti: periklanan, kampanye, pemberian hadiah, yang sering mempengaruhi penjualan (Basu Swasta \& Irawan, 1990)

Berikut respon dari Owner Prima Batik Kayu mengenai srategi meningkatkan omzet menurut mbak Iga Paulina, "Strategi yang saya gunakan dalam meningkatkan penjualan adalah dengan memanfaatkan fasilitas yang ada, yaitu dengan memanfaatkan fasilitas internet dari PT Telkom. Saya sering mengupdate postingan produk di instagram. Dari situ terlihat banyak konsumen yang merespon dan mulai membelinya. Meskipun tidak terlalu banyak konsumen biasa membeli 5 pcs, 10 pcs, dan terkadang juga 25 pcs tutur mbak Iga".

Berikut respon dari salah satu owner Sanggar Dewi Sri: "Dari beberapa sanggar yang ada di Krebet sepertinya sama keluhan dalam penurunan omzet maupun lainnya. Terkadang musim hujan/cuaca yang berganti-ganti. Musim hujan yang berkepanjangan juga menjadi momok bagi kita, karena kayunya banyak yang basah sehingga sulit untuk diproduksi. Terkadang konsumen atau pelanggan yang yang pesannya menurun karena kebutuhan yang terlalu banyak, dan yang harus kita ciptakan dari itu adalah selalu memiliki inovasi baru untuk membuat produk baru, sehingga menarik pelanggan untuk selalu mengupdate barang dari sanggar kita".

Dari hasil wawancara dengan para pengusaha batik kayu di dusun Krebet dapat disimpulkan bahwa fasilitas kabel optik/ program kampung UKM digital yang diberikan oleh PT Telkom peningkatan omzet penjualan. Akan tetapi dengan melihat data yang ada masih meninggalkan pertanyaan, apakah program kampung UKM digital PEMDA Bantul bekerja sama dengan PT Telkom sudah mempunyai dampak efektif sesuai dengan tujuan PEMDA Bantul dalam meningkatkan pertumbuhan ekonomi di pedesaan terutama para pelaku UKM.

\section{KESIMPULAN}

Berdasarkan hasil dan pembahasan penelitian ini, dengan menggunakan uji paired sample t-test dan uji wilxocon signed ranks test terhadap variabel omzet penjualan baik sebelum maupun sesudah menggunakan program kampung UKM digital dapat diambil kesimpulan bahwa terdapat perbedaan yang signifikan terhadap omzet penjualan antara sebelum dan sesudah menggunakan program kampung UKM digital dengan nilai t hitung sebesar -3,098 dan nilai signifikansinya sebesar 0,036 yang berarti lebih kecil dari tingkat signifikansi 0,05 (Ho ditolak). Sedangkan nilai pada uji wilxocon signed ranks test mempunyai taraf nilai Z sebesar -2,023, dengan signifikansi 2 -tailed sebesar 0,043 . Artinya nilai signifikansi $0,043<0,05$, maka Ho ditolak (ada perbedaan).

\section{DAFTAR PUSTAKA}

Aryanto, Arip dan Tri Irianto. 2012, "Pembangunan Sistem Penjualan Online Pada Toko Indah Jaya Furniture Surakarta": Journal Speed-Sentra Engineering dan edukasi, Vol. 4 No 4.

Budi Cahyono, Darmawan. 2013, “Pengguna Facebook Sebagai Media Pemasaran Online": Jurnal Kajian Ilmiah Mahasiswa Manajemen, Vol 2, No. 2

Deliusno, 2015. “Qlapa.Com, "Rumah" Bagi Produk Kerajinan Tangan Loka. Yogyakarta: Kompas.Com, (25 November 2015, 15:09)

Eunike dkk. 2014, "Faktor-Faktor Yang Mempengaruhi Keputusan Pembelian Pada Toko Fashion Di Jejaring Sosial Facebook": Jurnal Administrasi Bisnis, Vol 10, No. 1

Haryanti, Sri dan Tri Irianto. 2011, "Rancang Bangun Sistem Informasi E-commerce 
Untuk Usaha Fashion Studi Kasus Omah Mode Kudus": Journal Speed-Sentra Penelitian Engineering dan Edukasi, Vol. 3 No 1.

Muttaqin, Zainal. 2011, “Facebook Marketing Dalam Komunikasi Pemasaran Modern": Jurnal Teknologi, Vol 1.

Setiawati, Ira dan Agus Alwi Mashuri. 2014,

"Peran Media Sosial Sebagai Upaya Pemasaran Bisnis Online": Himsyatech -Jurnal Teknologi Informasi, Vol 10, No.2

SL. Trianingsih. 2011, "Dampak Online Marketing Melalui Facebook Terhadap Perilaku Konsumtif Masyarakat ": Jurnal ekonomi Dan Kewirausahaan Vol 11, No 2.

Supriadi, Endang. 2015, “Konstruksi Pembentukan Identitas Kampung Digital Samirono": Jurnal Ilmiah Sosiologi Agama, Volume 9, No.2.

Utantoro, Agus. 2016. Bantul Luncurkan Kampung UKM Digital. Yogyakarta: Media Indonesia, ( Rabu, 30 November 2016 ).

Febriarni, Uli. 2017. UKM Bantul Juga Dilengkapi Ketrampilan Digital.Yogyakarta: Harian jogja, ( 28 Januari 2017).

\section{BUKU;}

Al Qur'an dan Terjemahnya. 2007, Departemen Agama RI, Jakarta: Bumi Restu.

Algifari. 2010, Statistika Deskriptif Plus untuk Ekonomi dan Bisnis, Yogyakarta: Sekolah Tinggi Ilmu Manajemen YKPN.

Chaniago, A Arifinal. 1998, Ekonomi 2, Bandung: Angkasa.

Creswell John W. 2010, Research Design Pendekatan Kualitatif, Kuantitatif, dan Mixed, Yogyakarta: Pustaka Pelajar.

Departemen Pendidikan Nasional. 2002, Kamus Besar Bahasa Indonesia, Jakarta: Balai Pustaka.
Jeff Madura. 2007, Introduction to Bisnis, Pengantar Bisnis, Jakarta: Edisi 4, Salemba Empat.

Kotler dan Keller. 2007, Manajemen Pemasaran Edisi 12, Jilid 1, Jakarta: PT. Indeks.

Lasmadiarta Made. 2010, Faceebook Marketing Revolution, Jakarta: PT Elex Media Komputindo.

Levinson Jae Conrad dan Al Launtenslager. 2005, Guerrila Marketing in 30 Days, Yogyakarta: Andi.

Moleong Lexy J. 2005, Metodologi Penelitian Kualitatif, Bandung: Remaja Rosdakarya.

Morissan. 2007, Customer Behaviour: Conceps and Applications, New York: McGraw-Hill,Inc.

Sugiono. 2005, Metode Penelitian Bisnis, Bandung: Pusat Bahasa Depdiknas. . 2008, Metode Penelitian Kuantitatif Kualitatif Dan RED, Bandung: Alfabeta, 2010, Statistika Untuk Penelitian, Bandung: Alfabeta 2013, Metode Penelitian Kombinasi (Mixed Methods), Bandung: Alfabeta.

2014, Metode Penelitian Manajemen, Bandung: Alfabeta.

Supardi. 2005, Metode Penelitian Ekonomi Dan Bisnis, Yogyakarta.UII Press.

Swastha, Basu . 1993, Manajemen Penjualan, Jakarta: BPFE-UGM.

Swastha Basu dan Irawan. 1990, Manajemen Pemasaran Modern, Yogyakarta: Liberty.

Tika Moh Pabundu. 2006, Metodologi Riset Bisnis, Jakarta: PT.Bumi Aksara.

UmarHusein. 2000, Riset Pemasaran Dan Pelaku Konsumen, Jakarta: PT Gramedia Pustaka Utama

Uyung Sulaksana. 2003, Integrated Marketing Communications, Yogyakarta: Pustaka Pelajar.

Winardi. 1991, Pengantar Manajemen Penjualan, Bandung: Citra Adya Bahkti. 